\title{
EVALUATION OF THE AVAILABLE PLANT NUTRIENTS AT DIFFERENT PH LEVELS OF AHOKOR CLAY DEPOSIT LOCATED IN KOGI STATE, NIGERIA.
}

\author{
E. E. I. Irabor ${ }^{1}$, C. A. Unuigbe ${ }^{1}$, U. Omoruyi ${ }^{1}{ }^{*}$, K. O. EhimikhuaI ${ }^{1}$ and F. J. Sama ${ }^{1,2}$ \\ ${ }^{1}$ Department of Chemistry, University of Benin, Benin City, Edo State, Nigeria \\ ${ }^{2}$ School of Chemistry, Cardiff University, Park Place, Cardiff, CF10 3AT, United Kingdom. \\ *Corresponding Author: uwaila.omoruyi@uniben.edu; uwailaomo@gmail.com.+2348036624004
}

Received 30 May 2020; accepted 17 June 2020, published online 29 June 2020

\begin{abstract}
The nutrient level of Ahokor clay deposit in Kogi State, Nigeria was evaluated with the view of using it as a soil ammendments in soils deficient in plant mineral nutrients. Exchangeable bases (EB), cation exchange capacity (CEC), exchangeable acidity (EA) and percent base saturation were determined at five different $\mathrm{pH}$ levels for the top (LT) and bottom layers (LB) of the clay. These parameters were determined at $\mathrm{pH} 4, \mathrm{pH} 5, \mathrm{pH} 7, \mathrm{pH} 8$ and $\mathrm{pH} 9$ respectively. The exchangeable bases varied with change in $\mathrm{pH}$ with optimum values of $\mathrm{K}^{+}\left(1.120 \pm 0.300 \mathrm{cmolKg}^{-1}\right)$ and $\mathrm{Na}^{+}\left(0.701 \pm 0.010 \mathrm{cmolKg}^{-1}\right)$ for LT obtained at $\mathrm{pH} 7$ and $\mathrm{pH} 4$ respectively, while those of $\mathrm{Ca}^{2+}\left(0.920 \pm 0.025 \mathrm{cmolKg}^{-1}\right)$ and $\mathrm{Mg}^{2+}$ $\left(0.298 \pm 0.027 \mathrm{cmolKg}^{-1}\right)$ were recorded at $\mathrm{pH}$. Optimum values for the exchangeable bases for the bottom clay (LB) were recorded at $\mathrm{pH} 9$ with values of $0.536 \pm 0.020 \mathrm{cmolKg}{ }^{-1}, 3.522 \pm 0.023 \mathrm{cmolKg}^{-1}$, $1.959 \pm 0.020 \mathrm{cmolKg}^{-1}$ and $0.358 \pm 0.036 \mathrm{cmolKg}^{-1}$ recorded for $\mathrm{Na}^{+}, \mathrm{K}^{+}, \mathrm{Ca}^{2+}$ and $\mathrm{Mg}^{2+}$ respectively. The optimum condition for application as soil ammendment was obtained at pH9 as the percent base saturation which indicates that the crystal lattice is occupied with more of the desired base cations was highest at this $\mathrm{pH}$ for both layers.
\end{abstract}

Keywords: Exchangeable bases, cation exchange capacity, exchangeable acidity, perecent base saturation, soil fertility.

\section{INTRODUCTION}

Clay is a naturally occurring material composed primarily of fine-grained minerals, which is generally plastic at appropriate water contents and will harden when dried or fired [1]. Their particle sizes are less than 2 micrometers with negative charge sites capable of attracting cation within the soil [2]. From a chemical standpoint, clay can best be described as a hydrous aluminosilicate complex material arranged in well-defined octahedral and tetrahedral geometries resulting in closely packed layers or sheets $[3,4]$. Depending on the parent material of the clay, the surfaces of the aluminosilicate sheets may consist of either the oxygen anions and/or the hydroxyl ions organized into a closely packed hexagonal network. These anionic frameworks are neutralized by exchangeable bases (cations) held together by electrostatic force in their crystal lattice [5].

When clay is dispersed in water, the clay mineral ionizes and these ions are hydrated or solvated by water molecule in a process generally referred to as swelling [1]. Research has shown that the degree of swelling is largely dependent on the nature and amount of exchangeable bases (also reffered as exchangeable cations) present in the crystal lattice of the clay [6-8]. On the basis of this, clay have been classified as swelling (montmorillonite) and non-swelling (kaolinite) clay [9-11]. Furthermore, clay exhibit other properties such as shrinkage on drying or firing, firmness, colour retention hardness, cohesion etc. For these reasons, most clay deposits in Nigeria are widely mined for wide range of applications in different sectors of the economy. In the manufacturing industries, they are employed for products such as ceramics, glass, adhesives, paints, insulators etc [12-15]. In the oil and gas sector, clay is employed in drilling muds and in some cases as catalyst for petroleum cracking. In the agricultural sector they are employed in the manufacturing of 
fertilizers and in remediation of contaminated soils [16-18]. In whatever sector they are employed what is key to their application is an appreciable knowledge, information and under-standing of the chemical composition as well as mineralogy of the clay deposit. Thus in the agricultural sector, a vast body of literature exists on the cation exchange capacity (CEC) of clay which has fostered its application in remediation studies particularly in heavy metal clean ups [19-22]. However, there is a dearth of information on the direct application of clay on soil deficient of mineral nutrient to improve the soil fertility despite the fact that the crystal lattice of clay holds sufficient amount of the essential plant nutrients in the form of cations. For this to become a common practice, a good evaluation of exchangeable bases (EB) and cation exchange capacity of the clay deposits which are clearly indices of soil fertility as well as an understanding of factors such as $\mathrm{pH}$ that can influence their availability is necessary. Therefore in this study, soil fertility indices such as; the cation exchange capacity (CEC), exchangeable bases (EB), exchangeable acidity (EA) and percent base saturation of Ahokor clay deposit found in Kogi State Nigeria were evaluated to establish if this clay material can be used directly as a soil ammendment in soils showing nutrient deficiency. The evaluation was carried out at different $\mathrm{pH}$ levels with a view of establishing the best $\mathrm{pH}$ for optimum release of the clay mineral nutrient for possible plant uptake.

\section{EXPERIMENTAL}

\section{General information}

All regents and solvents were either purchased from Honeywell Fluka or BDH chemicals and used as received. Deionized water was used in all cases unless otherwise stated. The solutions containing exchangebale $\mathrm{Ca}^{2+}$ and $\mathrm{Mg}^{2+}$ were analyzed using atomic absorption spectrophotometer (AAS) Bulk Scientific 210VGP model. Solutions of exchangebale $\mathrm{K}^{+}$and $\mathrm{Na}^{+}$ were analysed using flame emission (FE) spectrophotometer Sherwood 410 model. Estimation of cation exchange capacity (CEC) was performed on a Jenway Uv-Vis spectrophotometer 6051 model. Exchangeable acidity (EA) and percent base saturation were mathematically determined using expressions 1 and 2 respectively.

$$
\begin{array}{r}
\mathrm{EA}=\mathrm{CEC}+\left(\mathrm{Na}^{+}+\mathrm{K}^{+}+\mathrm{Mg}^{2+}+\mathrm{Ca}^{2+}\right) \ldots \ldots \ldots \ldots . .(1) \\
\% \text { Base saturation }=\frac{\left(\mathrm{Na}^{+}+\mathrm{K}^{+}+\mathrm{Mg}^{2+}+\mathrm{Ca}^{2+}\right)}{100} \times 100 \ldots . .(2)
\end{array}
$$

Each experimentation was conducted in triplicate with corresponding mean and standard deviation calculated. All results were expressed as mean values with standard deviations.

\section{Sampling method / sample preparation}

Samples were obtained from a clay mineral deposit in Ahokor, Kogi state which is located in North Central Nigeria. Sampling of the clay materials into layers was based on colour variation in accordance with Uduji and co-workers [23]. The samples were air dried at room temperature, then pulverized mechanically afterwards, it was sieved using a $2 \mu \mathrm{m}$ sieve and activated in a Gallenkamp muffle furnace at $400{ }^{\circ} \mathrm{C}$ for 3 hours. The activated clay samples were subjected to different acid and alkaline media treatment for seventy two (72) hours, mechanically agitated for at least three (3) hours a day. Thereafter, the various parameters were determined viz cation exchange capacity (CEC), exchangeable bases (EB), exchangeable acidity (EA) and percent base saruration.

\section{Chemical analysis}

\section{Exchangeable bases (EB) and cation exchange capacity (CEC)}

The exchangeable bases $\left(\mathrm{Ca}^{2+}, \mathrm{Mg}^{2+}, \mathrm{K}^{+}, \mathrm{Na}^{+}\right)$and cation exchange capacities were determined following literarure methods [24-27]. To a clean $250 \mathrm{~mL}$ beaker was added $25 \mathrm{~g}$ of the pretreated clay sample and $125 \mathrm{~mL}$ ammonium acetate $\left(\mathrm{NH}_{4} \mathrm{OAc}\right)$ at $\mathrm{pH} 7$, the beaker was sealed with an aluminium foil. The mixture was agitated 3 hours daily on a mechanical shaker and allowed to stand for 3 days. Thereafter, clay- $\mathrm{NH}_{4} \mathrm{OAc}$ mixture was filtered through a Buchner funnel fitted with Whatman paper No. 1 under vacuum. The clay residue was then gently washed with $\mathrm{NH}_{4} \mathrm{OAc}(4$ $\times 25 \mathrm{~mL}$ ). All leachates were combined in a 250 $\mathrm{mL}$ volumetric flask and made to mark with $1 \mathrm{M}$ $\mathrm{NH}_{4} \mathrm{OAc}$ for elemental analysis $\left(\mathrm{Ca}^{2+}, \mathrm{Mg}^{2+}, \mathrm{K}^{+}\right.$, $\mathrm{Na}^{+}$) using instruments already mentioned above.

The residual clay sample was further washed with $95 \%$ ethanol $(6 \times 25 \mathrm{~mL})$ to remove excess 
$\mathrm{NH}_{4} \mathrm{OAc}$ and finally washed with $1 \mathrm{M} \mathrm{KCl}(5 \times$ $\mathrm{mL}$ ) to leach the adsorbed $\mathrm{NH}_{4}{ }^{+}$in the clay. Leachate from $\mathrm{KCl}$ washings were added up in $250 \mathrm{~mL}$ volumetric flask and made to volume by 1 $\mathrm{M} \mathrm{KCl}$ for $\mathrm{NH}_{4}$ determination in a colorimeter (Jenway 6051) at $636 \mathrm{~nm}$ according to Baethgen and Alley [26]. The same procedure was adopted for the other aqueous media with $\mathrm{pH} \mathrm{4,} \mathrm{5,} 8$ and 9 respectively. For determinations at $\mathrm{pH} 4$, the clay sample was first treated with $200 \mathrm{~mL}$ of $0.1 \mathrm{M}$ $\mathrm{HCl}$ and $0.1 \mathrm{M}$ potassium hydrogen phthalate (KHP) buffer 4 solution for 72 hours [28]. In like manner, estimations at $\mathrm{pH} 5$ were performed using $0.1 \mathrm{M} \mathrm{NaOH} / 0.1 \mathrm{M}$ KHP buffer system while determi-nations at $\mathrm{pH} 8$ and $\mathrm{pH} 9$ were achieved using $0.025 \mathrm{M}$ disodium tetraborate/ $0.1 \mathrm{M} \mathrm{HCl}$ buffer systems as decribed by Ribbison and stoke [28].

\section{RESULTS AND DISCUSSION}

The results for the exchangeable bases $\left(\mathrm{Ca}^{2+}\right.$, $\mathrm{Mg}^{2+}, \mathrm{K}^{+}, \mathrm{Na}^{+}$), cation exchange capacity (CEC), exchangeable acidity and percent base saturation
25

for the top layer (LT) and bottom layer (LB) of Ahokor clay at pH4, 5, 7, 8, and 9 are shown in Tables 1 and 2 respectively.

At the different $\mathrm{pH}$ values, exchangeable calcium cations $\left(\mathrm{Ca}^{2+}\right)$ were between $0.331 \pm 0.030 \mathrm{cmol}$ $\mathrm{kg}^{-1}$ and $0.920 \pm 0.025 \mathrm{cmolkg}^{-1}$ for the top layer (LT) while that of the bottom layer (LB) ranged between $0.331 \pm 0.030 \mathrm{cmolkg}^{-1}$ and $0.920 \pm 0.025$ $\mathrm{cmolkg}^{-1}$ for the top layer (LT). Values for the bottom layer (LB) ranged between $0.208 \pm 0.008$ $\mathrm{cmolkg}^{-1}$ and $1.959 \pm 0.020 \mathrm{cmolkg}^{-1}$. In both layer, the lowest and highest values of $\mathrm{Ca}^{2+}$ were recorded at $\mathrm{pH} 4$ and $\mathrm{pH} 9$ respectively. For exchangeable magnesium cations $\left(\mathrm{Mg}^{2+}\right)$, the highest concentra- tions were obtained at the alkaline $\mathrm{pH}$ of 9 for both layers with values of $0.298 \pm 0.027 \mathrm{cmolkg}^{-1}$ and $0.358 \pm 0.036 \mathrm{cmolkg}^{-1}$ recorded for LT and LB respectively. The lowest concentration of $\mathrm{Mg}^{2+}$ was observed at $\mathrm{pH} 4$ with values of $0.051 \pm 0.001 \mathrm{cmolkg}^{-1}$ and $0.035 \pm 0.003$ $\mathrm{cmolkg}^{-1}$ obtained for LT and LB respectively.

Table 1. Exchangeable Bases (EB), Cation Exchange Capacity (CEC), Exchangeable Acidity (EA) and Base Saturation (\%) obtained at different $\mathrm{pH}$ of Ahokor Clay top Layer (LT).

\begin{tabular}{|c|c|c|c|c|c|c|c|}
\hline \multirow[b]{2}{*}{ pH } & \multicolumn{6}{|c|}{$\mathrm{CmolKg}^{-1}$} & \multirow{2}{*}{$\begin{array}{l}\% \\
\text { Base } \\
\text { Sat. }\end{array}$} \\
\hline & $\mathbf{C a}$ & Mg & $\mathbf{K}$ & $\mathrm{Na}$ & CEC & EA & \\
\hline 4 & $0.331 \pm 0.030$ & $0.051 \pm 0.001$ & $0.816 \pm 0.090$ & $0.701 \pm 0.010$ & $6.991 \pm 0.293$ & $5.722 \pm 0.293$ & 27 \\
\hline 5 & $0.435 \pm 0.021$ & $0.113 \pm 0.013$ & $0.850 \pm 0.166$ & $0.162 \pm 0.018$ & $11.230 \pm 0.115$ & $9.673 \pm 0.115$ & 14 \\
\hline 7 & $0.886 \pm 0.020$ & $0.156 \pm 0.004$ & $1.120 \pm 0.300$ & $0.203 \pm 0.040$ & $15.648 \pm 0.290$ & $13.283 \pm 0.230$ & 15 \\
\hline 8 & $0.375 \pm 0.025$ & $0.088 \pm 0.004$ & $0.432 \pm 0.009$ & $0.177 \pm 0.018$ & $5.989 \pm 0.069$ & $4.917 \pm 0.069$ & 18 \\
\hline 9 & $0.920 \pm 0.025$ & $0.298 \pm 0.027$ & $0.159 \pm 0.008$ & $0.495 \pm 0.055$ & $6.394 \pm 0.126$ & $4.522 \pm 0.126$ & 29 \\
\hline
\end{tabular}

Table 2. Exchangeable Bases (EB), Cation Exchange Capacity (CEC), Exchangeable Acidity (EA) and Base Saturation (\%) obtained at different $\mathrm{pH}$ of Ahokor Clay bottom Layer (LB).

\begin{tabular}{cccccccc}
\hline & \multicolumn{9}{c}{$\mathbf{c}$} & \multicolumn{2}{c}{$\mathrm{CmolKg}^{-1}$} & & $\%$ \\
$\mathbf{n n y y y y y n}$ & $\mathbf{N H}$ & $\mathbf{M g}$ & $\mathbf{K}$ & $\mathbf{N a}$ & $\mathbf{C E C}$ & $\mathbf{E A}$ & $\begin{array}{l}\text { Base } \\
\text { Sat. }\end{array}$ \\
\hline 4 & $0.208 \pm 0.008$ & $0.035 \pm 0.003$ & $1.022 \pm 0.041$ & $0.080 \pm 0.003$ & $3.983 \pm 0.082$ & $2.631 \pm 0.082$ & 34 \\
5 & $0.287 \pm 0.090$ & $0.078 \pm 0.006$ & $1.177 \pm 0.093$ & $0.155 \pm 0.008$ & $6.678 \pm 0.157$ & $5.071 \pm 0.157$ & 25 \\
7 & $0.882 \pm 0.048$ & $0.200 \pm 0.007$ & $1.307 \pm 0.047$ & $0.185 \pm 0.025$ & $14.505 \pm 0.300$ & $2.594 \pm 0.300$ & 18 \\
8 & $0.630 \pm 0.017$ & $0.068 \pm 0.004$ & $0.120 \pm 0.013$ & $0.183 \pm 0.022$ & $4.748 \pm 0.068$ & $2.747 \pm 0.068$ & 21 \\
9 & $1.959 \pm 0.020$ & $0.358 \pm 0.036$ & $3.522 \pm 0.023$ & $0.536 \pm 0.020$ & $7.055 \pm 0.083$ & $0.680 \pm 0.083$ & 90 \\
\hline
\end{tabular}


The values for exchangeable potassium cations $\left(\mathrm{K}^{+}\right)$ranged between $0.159 \pm 0.008 \mathrm{cmolkg}^{-1}$ and $1.120 \pm 0.300 \mathrm{cmolkg}^{-1}$ for LT, while the values obtained for LB were between $0.120 \pm 0.013$ $\mathrm{cmolkg}^{-1}$ and $3.522 \pm 0.023 \mathrm{cmolkg}^{-1}$. For LT, the highest value for $\mathrm{K}^{+}\left(1.120 \pm 0.300 \mathrm{cmolkg}^{-1}\right)$ was obtained at a neutral $\mathrm{pH}(\mathrm{pH} 7)$. Although the highest values for $\mathrm{K}^{+}$in the bottom layer (LB) was recorded at $\mathrm{pH} 9\left(3.522 \pm 0.023 \mathrm{cmolkg}^{-1}\right)$, the value at $\mathrm{pH} 7\left(1.307 \pm 0.047 \mathrm{cmolkg}^{-1}\right)$ was higher than the highest value obtained for the top layer (LT) clay. Exchangeable sodium cations $\left(\mathrm{Na}^{+}\right)$ were between $0.162 \pm 0.018 \mathrm{cmolkg}^{-1}$ and $0.701 \pm 0.010 \mathrm{cmolkg}^{-1}$ for LT with the lowest and highest values recorded at $\mathrm{pH} 5$ and $\mathrm{pH} 4$ respectively. The $\mathrm{Na}^{+}$values for $\mathrm{LB}$ ranged between $0.080 \pm 0.003 \mathrm{cmolkg}^{-1}$ and $0.536 \pm 0.020$ $\mathrm{cmolkg}^{-1}$ with the minimum and optimum values recorded at $\mathrm{pH} 4$ and $\mathrm{pH} 9$ respectively.

Overall, there was a gradual increase in $\mathrm{Ca}^{2+}, \mathrm{Mg}^{2+}$ and $\mathrm{K}^{+}$values from the acidic medium to the neutral medium and a drop from the neutral to the alkaline medium. However, increase in $\mathrm{pH}$ in the acidic and alkaline media resulted in an increase in the concentrations in $\mathrm{Ca}^{2+}, \mathrm{Mg}^{2+}$ and $\mathrm{K}^{+}$. The ratio of exchangeable calcium to exchangeable magnesium $(\mathrm{Ca} / \mathrm{Mg})$ provides a guide to a soil's structure which in turn influences soil drainage, root development and subsequent plant growth [29]. Well-structured soils have a $\mathrm{Ca} / \mathrm{Mg}$ ratio greater than 2:1, in other words, the amount of calcium cations is more than two times greater than the amount of magnesium cations $[29,30]$. In the results obtained from the analysis of Ahokor clay at the various $\mathrm{pH}$ (Table 1 and 2), $\mathrm{Ca}^{2+}$ was twice the amount of $\mathrm{Mg}^{2+}$ ion. Hence, Ahokor clay may be useful in enhancing soil structure. Potassium $\left(\mathrm{K}^{+}\right)$, calcium $\left(\mathrm{Ca}^{2+}\right)$ and magnesium $\left(\mathrm{Mg}^{2+}\right)$ are among the essential elements required by plants [31]. From the results obtained for Ahokor clay, $\mathrm{K}^{+}, \mathrm{Mg}^{2+}$ and $\mathrm{Ca}^{2+}$ are in sufficient amounts for plant uptake. Potassium $\left(\mathrm{K}^{+}\right)$has substantial effect on enzyme activation, protein synthesis, photosynthesis, stomata movement and water-relation (turgor regulation and osmotic adjustment) in plants [32]. In addition, increased applications of $\mathrm{K}^{+}$have been shown to enhance photosynthetic rate, plant growth, yield and drought resistance in different crops under water stress conditions [33-36]. From our analysis, $\mathrm{K}^{+}$is the predominant exchangeable base present in Ahokor clay with both layers containing huge amount of the cations at the different $\mathrm{pH}$ levels screened, although the bottom layer is richer in $\mathrm{K}^{+}$ ion.

Cation Exchange Capacity (CEC) is the sum total of exchangeable cations that are adsorbed and is a measure of the ability of a clay to hold cations [37]. CEC is widely used in the characterizing clay as it determines soil fertility; the higher the CEC value, the higher the fertility of the soil [38]. Thus, clay with high CEC have the ability to hold more cations making them sufficient in calcium, magnesium and other cations and therefore a higher ability to hold water (swelling property) [6]. The cation exchange capacity (CEC) for LT ranged between $5.989 \pm 0.069 \mathrm{cmolkg}^{-1}$ and $15.648 \pm 0.290 \mathrm{cmolkg}^{-1}$, while the CEC values for $\mathrm{LB}$ were between $3.983 \pm 0.082 \mathrm{cmolkg}^{-1}$ and $14.505 \pm 0.300 \mathrm{cmolkg}^{-1}$. A strong relationship exist between the $\mathrm{pH}$ and the CEC of Ahokor clay, as the $\mathrm{pH}$ was seen to directly influence the CEC values of clay in both the acidic and alkaline media. In both layers, there was a steady increase in CEC values from the acidic medium $(\mathrm{pH} 4)$ to the neutral $\mathrm{pH}(\mathrm{pH} 7)$ and a decline in the alkaline medium at the top layer (LT) but varied in pattern at the bottom layer. However, the CEC value at $\mathrm{pH} 9$ was higher than $\mathrm{pH} 8$ in both layers. The CEC values followed the order $\mathrm{pH} 7>\mathrm{pH} 5>\mathrm{pH} 4$ $>\mathrm{pH} 9>\mathrm{pH} 8$ for LT, while that of LB was $\mathrm{pH} 7>$ $\mathrm{pH} 9>\mathrm{pH} 5>\mathrm{pH} 8>\mathrm{pH} 4$. In both layer, the optimum CEC values was recorded at $\mathrm{pH} 7$, hence at $\mathrm{pH} 7$, Ahokor clay holds more cations than the other respective $\mathrm{pH}$ screened.

Exchangeable Acidity (EA) is a measure of the acidic hydrogen and aluminum cations held on negatively charged sites of clay. For LT, the highest EA was recorded at $\mathrm{pH} 7(13.283 \pm 0.230$ $\left.\mathrm{cmolkg}^{-1}\right)$ followed closely at pH $5(9.673 \pm 0.115$ $\mathrm{cmolkg}^{-1}$ ) while the minimum EA value of $4.522 \pm 0.126 \mathrm{cmolkg}^{-1}$ was recorded at $\mathrm{pH} 9$. For the bottom clay (LB), the minimum and optimum EA values of $0.680 \pm 0.083 \mathrm{cmolkg}^{-1}$ and $5.071 \pm 0.157 \mathrm{cmolkg}^{-1}$ was obtained at $\mathrm{pH} 9$ and pH5 respectively. Ahokor clay was more saturated with the acidic cations (EA) relative to the exchangeable bases or cations. This was further evident in the percent base saturations estimated at 
the different $\mathrm{pH}$ levels for both top layer (LT) and bottom layer (LB) of the clay as displayed in Table 1 and 2 respectively. The base saturation ranged between $14 \%$ and $29 \%$ for LT, while that of LB were between $18 \%$ and $90 \%$. The highest percent base saturation was recorded at $\mathrm{pH} 9$ for both layer with the respective value of $29 \%$ and 90\% recorded for LT and LB.

The results obtained from the analysis of the Ahokor clay showed that pH9 is the optimum condition for application as soil blend. At this $\mathrm{pH}$, the clay contains the highest concentration of base saturation and also holds sufficient amount of all exchangeable bases especially potassium $\left(\mathrm{K}^{+}\right)$ion. Potassium $\left(\mathrm{K}^{+}\right)$is a macronutrient required by plants thus, using Ahokor clay directly as a soil ammendment in soils showing nutrient deficiency, would provide the necessary buffer against acid generated from plant root and soil reaction processes [36].

\section{CONCLUSION}

The nutrient level of Ahokor clay deposit located obtained in Kogi State, Nigeria for plant uptake was evaluated. The exchangeable bases (EB), cation exchange capacity (CEC), exchangeable acidity (EA) and percent base saturation at five different $\mathrm{pH}$ levels $(4,5,7,8$ and 9) for the top (LT) and bottom (LB) layers of the clay were studied. Our findings showed that both layers of the clay were rich in the plant nutrient cations particularly the much needed potassium cations $\left(\mathrm{K}^{+}\right)$. Furthermore, $\mathrm{pH} 9$ was found to be the optimum condition for direct application on soil deficient in soil nutrients. In addition, Akohor clay deposit holds promise as a potential raw material in the production of NPK (Nitrogen, Phosphorus and Potassium) fertilizer due to its richness in potassium cations.

\section{REFERENCES}

1. I. Abubakar, U. A. B. Yauri, U. Z. Faruq, S. S. Noma and N. Sharif, (2014). Characterization of Dabagi clay deposit for its ceramics potential. African J. Environ. Sci. Technol. 8, 455-459.
2. B. Velde, Composition and Mineralogy of Clay Minerals. in Origin and Mineralogy of Clays 842 (Springer, 1995).

3. H. H. Murray, (1999) Applied clay mineralogy today and tomorrow. Clay Miner. 34, 39-49.

4. F. O. Aramide, K. K. Alaneme, P. A. Olubambi and J. O. Borode, (2014). Characterization of some clay deposits in South West Nigeria. Leonardo Electron. J. Pract. Technol. 13, 4657.

5. V. I. Osipov, (1975). Structural bonds and the properties of clays. Bull. Int. Assoc. Eng. Geol.Bull. l'Association Int. Géologie l'Ingénieur 12, 13-20.

6. P. F. Low, (1981).The Swelling of Clay: III. Dissociation of Exchangeable Cations. Soil Sci. Soc. Am. J. 45, 1074-1078.

7. A. Chatterjee, T. Ebina, Y. Onodera and F. Mizukami, (2004). Effect of exchangeable cation on the swelling property of 2:1 dioctahedral smectite - A periodic first principle study. J. Chem. Phys. 120, 34143424.

8. D. A. Laird, (2006). Influence of layer charge on swelling of smectites. Appl. Clay Sci. 34, 74-87.

9. B. Velde, Introduction to Clay Minerals Chemistry, Origins, Uses and Environmental Significance Chapman and Hall, London, 1992, pp 12.

10. A.Steudel, L. F. Batenburg, H. R. Fischer, P. G. Weidler and K. Emmerich, (2009). Alteration of non-swelling clay minerals and magadiite by acid activation. Appl. Clay Sci. 44, 95-104.

11. R. L. Anderson, I. Ratcliffe, H. C. Greenwell, P. A. Williams, S. Cliffe and P. V. Coveney, (2010). Clay swelling - A challenge in the oilfield. Earth-Science Reviews 98, 201-216.

12. B. C. Chukwudi, (2008). Characterization and Evaluation of the Refractory Properties of Nsu Clay Deposit in Imo State Nigeria. Pacific J. Sci. Technol. 9, 487-494.

13. O. Akhirevbulu, C. Amadasun, M. Ogunbajo, and O. Ujuanbi, (2011). The Geology and Mineralogy of Clay Occurrences Around Kutigi Central Bida Basin, Nigeria. Ethiop. J. Environ. Stud. Manag. 3, 49-56.

14. C. G. Ituma, A. B. Etukudoh, M. A. Abuh, K. G. Akpomie and C. I. Obioha, (2018). Utilization of Nkpuma-Akpatakpa clay in 
ceramics: characterization and microstructural studies. J. Appl. Sci. Environ. Manag. 22, 47.

15. A. A. Jock, F. A. Ayeni, A. S. Ahmed and U. A. Sullayman, (2013). Evaluation of the Refractory Properties of Nigerian Ozanagogo Clay Deposit. J. Miner. Mater. Charact. Eng. 01, 321-325.

16. O. Friday, A. Bisong, and M.-K. Achu, (2017). Assessment of the Industrial Potentials of Some Nigerian Kaolinitic Clay Deposits. Eur. J. Eng. Technol. 5, 48-56.

17. O. O. Ojuri, S. A. Ola, O. G. Fadugba and M. Uduebor. Fourth International Conference on Geotechnique, Construction Materials and Environment. in Site remediation in Nigeria: proven and innovative technologies (recovery of free hydrocarbon from soil/groundwater) Geomate International Society, Brisbane, Australia (2014), 585-590.

18. K. G. Akpomie, C. F. Onyeabor, C. C. Ezeofor, J. U Ani and S. I. Eze, (2019),Natural aluminosilicate clay obtained from southeastern Nigeria as potential sorbent for oil spill remediation. J. African Earth Sci. 155, 118123.

19. F. F. O. Orumwense, (1996). Removal of Lead from Water by Adsorption on a Kaolinitic Clay. J. Chem. Technol. Biotechnol. 65, 363-369.

20. E. Ajenifuja, O. O. Akinwunmi, M. K. Bakare, J. A. Ajao, I. F. Adeniyi and E. O. B. Ajayi, (2012). Remediation of Polluted Water Using Natural Zeolitic Aluminosilicates / Lateritic Clay Ceramic Matrix Membrane. ISRN Ceram. 2012, 1-10.

21. F. A. Dawodu and K. G. Akpomie, (2014). Simultaneous adsorption of $\mathrm{Ni}$ (II) and $\mathrm{Mn}$ (II) ions from aqueous solution unto a Nigerian kaolinite clay. J. Mater. Res. Technol. 3, 129141.

22. O. Olaofe, S. A. Olagboye, P. S. Akanji, E. Y. Adamolugbe, O. T. Fowowe and A. A. Olaniyi, (2015. Kinetic Studies of Adsorption of Heavy Metals on Clays Kinetic Studies of Adsorption of Heavy Metals on Clays. Int. J. Chem. 7, 48-54.

23. E. R. Uduji, C. O. Okagbue, T. U.S . Onyeobi, (1996). Geotechnical properties of soils derived from the Awgu and Mamu formations in the Awgu-Okigwe area of south-eastern Nigeria and their relations to engineering problems. Int.
J. Rock Mech. Min. Sci. Geomech. Abstr. 33, 16A.

24. H. D. Chapman, Cation-Exchange Capacity, in C. A. Black (Ed.), Methods Soil Anal. Part 2 Chem. Microbiol. Prop. 9.2, 2nd Edition, American Society of Agronomy, Madison, USA, 1965, p.894-89.

25. G. P. A Gillman, (1979). Proposed method for the measurement of exchange properties of highly weathered soils. Aust. J. Soil Res. 17, 129-139.

26. W. E. Baethgen, and M. M. Alley, (1989). A manual colorimetric procedure for measuring ammonium nitrogen in soil and plant kjeldahl digests. Commun. Soil Sci. Plant Anal. 20, 961969.

27. A. Chimdi, H. Gebrekidan, K. Kibret and A. Tadesse, (2012). Status of selected physicochemical properties of soils under different land use systems of Western Oromia, Ethiopia. J. Bio. Env. Sci. 2, 57-71.

28. R. A. Robinson, and R. H. Stokes, (1965). No Electrolyte solutions: the measurement and interpretation of conductance, chemical potential, and diffusion in solutions of simple electrolytes. Butterworths Scientific Publications, London, United Kingdom.

29. I. O. Osemwota, J. A. I. Omueti, and A. I. Ogboghodo, (2007). Effect of Calcium / Magnesium Ratio in Soil on Magnesium Availability, Yield, and Yield Components of Maize. Commun. Soil Sci. Plant Anal. 38, 2849-2860.

30. M. Salihaj, and A. Bani, (2018). Chemical Properties of Serpentine Soils from Kosovo Chemical Properties of Serpentine Soils from Kosovo. Albanian J. Agric. Sci. 17, 78-83.

31. D. E. Kissel, L. Sonon, P. F. Vendrell, and R. A. Isaac, (2009). Salt concentration and measurement of soil pH. Commun. Soil Sci. Plant Anal. 40, 179-187.

32. H. Marschner, (2012). Marschner's Mineral Nutrition of Higher Plants, 3rd Edition, Academic Press, San Diego, California, USA.

33. J. N. Egilla, F. T. Davies and M. C. Drew, (2001). Effect of potassium on drought resistance of Hibiscus rosa-sinensis cv. Leprechaun: Plant growth, leaf macro- and micronutrient content and root longevity. Plant Soil 229, 213-224. 
34. N. A. Mohd Zain, M. R. Ismail, A. Puteh, M. Mahmood and M. R Islam, (2014). Drought Tolerance and Ion Accumulation of Rice Following Application of Additional Potassium Fertilizer. Commun. Soil Sci. Plant Anal. 45, 2502-2514.

35. Z. Z. Song, S. Y. Yang, J. Zuo and Y. H. Su, (2014). Over-expression of ApKUP3 enhances potassium nutrition and drought tolerance in transgenic rice. Biol. Plant. 58, 649-658.

36. M. A. Ahanger, N. S. Tomar, M. Tittal, S. Argal and R. M. Agarwal, (2017). Plant growth under water/salt stress: ROS production; antioxidants and significance of added potassium under such conditions. Physiol. Mol. Biol. Plants 23, 731-744.
37. B. W. Bache, (1976). The measurement of cation exchange capacity of soils. J. Sci. Food Agric. 27, 273-280.

38. F. Bergaya and M. Vayer, (1997). CEC of clays: Measurement by adsorption of a copper ethylenediamine complex. Appl. Clay Sci. 12, 275-280. 